the structures of two orogenies, but are due to the twisting of the northeasterly structures through $90^{\circ}$; the gradual swing-round of these structures can also be observed in the field.

There are, it is true, two fold-phases in South-West Donegal ; the evidence, however, points to the bending sideways, about roughly vertical axes, of original north-easterly structures. Far from being mechanically impossible, such distortion will take place if the direction of minimum compression is not vertical but in a horizontal direction either locally or regionally. The South-West Donegal structures can also be simulated in plasticine!

Although plasticine models prove useful qualitative methods of demonstrating possible mechanisms which have led to the evolution of complex structures, the attempt of the authors to establish a quantitative correlation with actual rock-deformation can only be described as naive. For example, the physical state of rocks undergoing a second folding after earlier folding and regional metamorphism is very different from that of sediments undergoing primary folding; no comparable change is, however, made in the physical state of the plasticine between the two foldings. The time-factor is not introduced into the scale-correlation at all although those concerned with soil mechanics will know that the rate of loading is of prime importance. The figure given for the strength of quartzite is presumably that for the crushing strength under unidirectional stress and certainly bears no relationship to its virtually unknown strength under the conditions of crustal folding and regional metamorphism, a point about which the authors themselves have apparently had some misgivings.

If the strength given for plasticine is also that under unidirectional stress, no proof is advanced that this bears a significant relationship to its strength under the stress-conditions of the experiment, which in fact are not stated. The authors, it is true, attempt to relate the varying strengths of differently coloured plasticine to the strength of different rock-types, but they offer no proof that such differences are of the same order as those between, say, psammitic, pelitic, and calcareous rocks which have undergone crustal deformation.

Those who would base structural theories on plasticine and other experiments, would do well to consider the observations of Dr. Terzaghi on standard and fundamental strengths in a discussion published in the Quarterly Journal of the Geological Society for 1946.

\title{
REFERENCES
}

Anderson, J. G. C., 1954. The Pre-Carboniferous rocks of the Slieve League Promontory, Co. Donegal, Quart. Journ. Geol. Soc., cix, 399-422.

Reynolds, D. L., and A. Holmes, 1954. The Superposition of Caledonoid Folds on an Older Fold-System in the Dalradians of Malin Head, Co. Donegal. Geol. Mag., xci, 417-444.

Terzaghi, K., 1946. In Discussion of Papers published in previous volumes of the Quart. Journ. Geol. Soc., cii, 203-204.

DeParTMENT OF GeOlogy,

UNIVERSITY COLLEGE,

J. G. C. ANDERSON.

NewPort Road, Cardiff.

22nd December, 1954.

\section{FOLDED FRACTURE CLEAVAGE IN THE SOUTHERN HIGHLANDS : PRELIMINARY NOTE}

SIR,-The Ben Ledi Grits form part of an extensive outcrop of Dalradian schistose greywackes that stretches across the Scottish Highlands close to their southern border. This note draws attention to the portion of this outcrop that lies north-east of Loch Achray between Loch Katrine and 
Loch Venachar in the Southern Highlands of Perthshire, and to the north of the Aberfoyle Slate belt. Here it has been found that the grits form two contrasted areas, a north-western area of strongly folded fracture cleavage, and a south-eastern belt of unfolded fracture cleavage. Both areas are in a low grade of metamorphism and are composed of the same grits or greywackes, chiefly containing quartz, with chlorite, white mica, and some alkali-feldspar.

Readily accessible exposures in the belt of folded cleavage occur around the lower reaches of the River Turk for a mile or so up-stream of Brig O' Turk, and for about the same distance along the main road from Brig O' Turk towards the Trossachs Hotel. These exposures display well-developed straight parallel fracture cleavage planes usually $\frac{1}{8}$ in. to $\frac{1}{2}$ in. apart, dipping north from 40 to 60 degrees, along which the chlorites and micas are often strongly concentrated to give a strikingly pronounced fine banding to the rocks. The character of this banding seems such as to preclude its sedimentary origin in rocks of greywacke composition, and this impression has been proved correct at several places in the hills immediately north of Loch Achray. There the fracture cleavage abuts against strong and visually uncleaved sedimentary beds, the fracture cleavage planes striking east-west and the sedimentary beds south-west-north-east. Also, bedding crossed by the cleavage has been noted in cores of bores put down at a proposed engineering site in Glen Finglas. The compositional banding parallel to the fracture cleavage planes is concluded to be the result of metamorphic differentiation controlled by the cleavage.

North of a line that has been followed for about 2 miles roughly northeastwards from the vicinity of the Trossachs Hotel across Sron Armailte and the River Turk, a striking change takes place. The fracture cleavage planes are affected by intense small scale folding well seen on Creag Mhòr and in Glen Finglas on Geal Chreagain. This strongly crumpled zone extends northwards from its south-eastern boundary for about two miles at least into Creag na h-Airidh. In places the crumpling is accompanied by a later set of strain-slip cleavage planes.

The structures in the crumpled and the non-crumpled belts are at present being studied for a few miles on either side of the boundary between the belts, and this boundary will be followed in either direction across country as far as it may extend. It is hoped to determine the precise meaning of the boundary, which has been located within 100 yards on Sròn Armailte, and a useful section across it should be provided by a tunnel in course of being driven through the hills between Glen Finglas and Loch Katrine in connection with a Glasgow Corporation Waterworks scheme.

To one of us (J. E. R.) this juxtaposition of two sharply contrasted structural styles in the Southern Highlands is of particular interest because of a similar relationship in Inverness-shire on the western side of the Morar anticline. The evenly foliated Moine schists of Morar and the highly contorted Sub-Moine rocks of Morar in the core of the Morar anticline are distinctive structural units almost everywhere separable by a mappable line the significance of which is at present not fully understood.

It is interesting to recall that in the schistose greywackes of the Cowal district some 40 miles or so south-west of the Trossachs, Clough (1897) recognized folded "strain-slip" cleavage and also several sets of cleavage belonging to different episodes in the tectonic history of that classic area.

\section{REFERENCE}

Clough, C. T., 1897, in The Geology of Cowal (Mem. Geol. Surv. Scotland).

Department of Geology,

QueEn's COLlEGE, DundeE.

17th December, 1954. 